\title{
Some segmental morphological and morphometrical features of the intima and media of the aortic wall in Chinchilla lanigera
}

\author{
C.O. Martonos', A.I. Gudea1', A. Damian1', V. Miclăuș², V. Rus², F.G. Stan¹ \\ ${ }^{1}$ Department of Comparative Anatomy, Faculty of Veterinary Medicine Cluj-Napoca, University of Agricultural Sciences \\ and Veterinary Medicine Cluj-Napoca, Romania \\ ${ }^{2}$ Department of Histology, Faculty of Veterinary Medicine Cluj-Napoca, University of Agricultural Sciences and Veterinary \\ Medicine Cluj-Napoca, Romania
}

[Received: 14 December 2018; Accepted: 4 February 2019]

\begin{abstract}
Background: The aim of this study is to describe the morphology, morphometry and ultrastructure of segments of the thoracic and abdominal aorta portions in Chinchilla lanigera. Thickness measurements of the tunica intima and media complex of the aorta were taken.

Materials and methods: In all observed specimens, the thickness values for the tunica intima and media complex of the cranial thoracic aorta were significantly higher (mean: $702.19 \mu \mathrm{m}$ ) when compared to the values of other analysed aortic segments (means: $354.18 \mu \mathrm{m} ; 243.55 \mu \mathrm{m}$ ). Complex statistical methods were used to assess the differences between various aortic segments.

Results and Conclusions: The components of the vessel walls show variations in structure and thickness, presumably due to an adaptation to functional demand. (Folia Morphol 2019; 78, 4: 729-737)
\end{abstract}

Key words: arteries, chinchilla, aorta, quantitative histological, qualitative histological, media, intima, post hoc

\section{INTRODUCTION}

Chinchilla lanigera is a rodent species belonging to the Chinchillidae family, originating from the central Andes in Chile, Peru and Bolivia. Chinchillas are mainly kept for fur, but also as pets [33] or, lately, as laboratory animals. They are used in experimental medicine in the study on middle otitis or parasitology $[1,13-15,18]$.

The structural description of the aortic wall has been published for several species, like humans [8], common and laboratory rat $[2,16,36]$, dog [27] goat $[24,25]$, paca [10], opossum [19], capucin chicken [23] and gerbil [26], but, to the best of our knowledge, such a description has never been made for chinchilla. More than that, there is no significant combined morphological and morphometrical description of the layers of the arteries in this species.

Aorta, in all mammals, is the main vessel, part of the greater circulation, which ensures the distribution of blood from the heart to most of the body. It originates at the base of the hearth - ascending aorta (aorta ascendens), passing through the thoracic and abdominal cavities, giving off visceral and parietal branches [3]. A set of vessel are directed towards the head, neck and forelimb, originating from the level of the aortic arch (aorta ascendens-arcus aortae) while

Address for correspondence: A.I. Gudea, Associate Professor, Department of Comparative Anatomy, Faculty of Veterinary Medicine Cluj-Napoca, University of Agricultural Sciences and Veterinary Medicine Cluj-Napoca, 3-5 Manastur str, 400372, Cluj-Napoca, Romania, tel: +40-264-596.384, fax: +40-264-593.792, e-mail: alexandru.gudea@usamvcluj.ro 
within the thoracic cavity (aorta descendens-aorta thoracica), a series of branches are distributed by means of parietal and visceral branches. The aorta crosses the diaphragmatic hiatus to distribute both visceral and parietal branches within the abdominal cavity (aorta descendens, aorta abdominalis).

The macroscopic pattern of distribution of some aorta-originating branches has been described lately in a series of studies in chinchilla [20,29-31] or other rodents $[5,34]$.

Structurally, the arterial segments have been classified into elastic, transitional and muscular types based on the histological characteristics and organisation of connective tissue fibres and smooth muscle cells in three distinct tunics: tunica intima, tunica media and tunica adventitia [9].

The intima is the most innermost layer that comes in direct contact with the blood flow and it comprises a flattened endothelial layer placed on a basal membrane, a subendothelial layer formed by conjunctive tissue (elastic fibres, reticular fibres and collagenous fibres) and an internal elastic limiting membrane. The media consists of muscular cells arranged in a circular direction with a certain amount of elastic and collagenous fibres interposed. The adventice (outer layer) contains elastic and collagen fibres along with some muscular fibres in a relatively little organised form.

The main objective of this study is to describe the structure of the aortic segments and other morphological features, including the morphometrical data of the intima and media, as observed in light microscope in chinchilla. More than that, an advanced statistical approach is used to check whether the method can be used as indicator for some fine differences that cannot be perceived by a regular histological investigation.

\section{MATERIALS AND METHODS}

The biological material was represented by 15 adult chinchilla individuals, originating from a private breeder, commercially slaughtered for fur. After the skinning, the carcasses were anatomically dissected, following the regular procedure. The aortic segments were identified, following the abdominal wall and sternum dissection. The aorta was fixed by slow $4 \%$ formalin perfusion through the ventricular cavity as the right atrium was sectioned to allow blood outflow. The dissection of the aorta followed, with the proper removal of parts of the four mentioned fragments (ascending aorta, arcus aortic, tho- racic and abdominal aorta). Collected fragments were further fixed in $4 \%$ formalin and followed the routine histological procedure. Fixation was performed in Stieve fixative fluid for $24 \mathrm{~h}$, dehydrated in ethyl alcohol ( 2 times for $2 \mathrm{~h}$ succeeding immersions) followed by another passage in absolute ethanol for another $1.5 \mathrm{~h}$. The last tissue clearing was performed with butyl alcohol (3 times, $24 \mathrm{~h}$ ) and further on paraffin included. Serial sections of $5 \mu \mathrm{m}$ were cut and the trichrome Goldner-Verhoeff staining method was applied on the samples [17].

All the histological material was analysed and photographically documented by using an optic microscope Olympus BX 41 device with a digital Olympus E330 camera. The captured images were furthermore processed with Gimp or Image ${ }^{\circledR}$ software for the histological measurements. Several measurements were made on the vascular tunics and on the elastic laminae.

In order to highlight the possible statistical differences among the studied segments, a series of advanced statistical tests were performed on the available data series for the taken measurements.

Due to unequal sample series, the post hoc tests seem suitable for the comparison of the distribution of the mean values. Out of the typical tests, the Tukey, Scheffe, Holm and Bonferroni tests were used and their results were compared. The statistical tests were performed in accordance to: http://astatsa.com/ OneWay_Anova_with_TukeyHSD/.

\section{Statistical analysis}

For each studied morphological entity, the series of statistical tests was performed (one way ANOVA). The next tests were applied based on the F-value which had been provided by the previous tests $(F \leq 0.005)$.

\section{RESULTS}

\section{Qualitative analysis - general data}

Ascending aorta. The media of this segment is very thick, with a relatively ordered structure, the elastic component clearly prevailing. In this layer, the circularly placed elastic laminae are very clearly visible on Verhoeff staining (Fig. 1). The interlaminar spaces were larger in the inner half of the media while the outermost half seems to present narrower interlaminar spaces, due to the accentuated coarseness of the thinner elastic laminae. The interlaminar spaces present circular bundles of smooth muscle cells embedded in connective tissue in a peculiar arrange- 


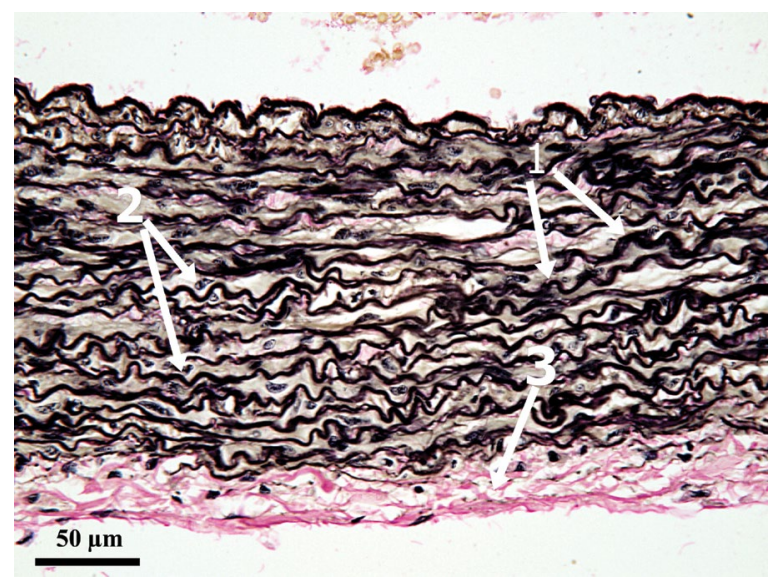

Figure 1. Ascending aorta (Verhoeff); 1 - elastic laminae; 2 - smooth muscle cell nuclei; 3 - adventice.

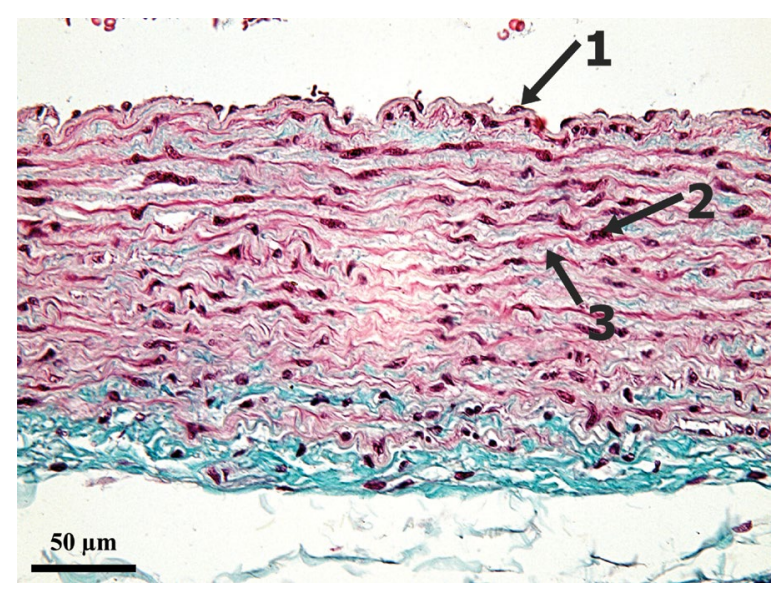

Figure 2. Ascending aorta (Trichrome Goldner); 1 — intima; 2 - connective tissue of media; 3 - muscle cells of the media; 4 - adventice.

ment, forming a single row of muscular cells flanked by two elastic neighbouring laminae (Fig. 2). The internal limiting membrane appears thin, but clearly visible on trichrome staining. The external limiting membrane seems difficult to identify.

Aortic cross. This sector has lot of the features found on the ascending aorta. The internal limiting membrane is less distinctive as in the ascending aorta. Media prevails, as the structure is predominantly elastic as well. The number of elastic laminae is similar with the one recorded in the case of the ascending aorta, but a slight difference is to be noted when shape and disposition is taken in consideration. The elastic laminae are slightly thicker and less folded, except for the anterior third of the aortic cross where these differences are not distinguishable (Fig. 3). The

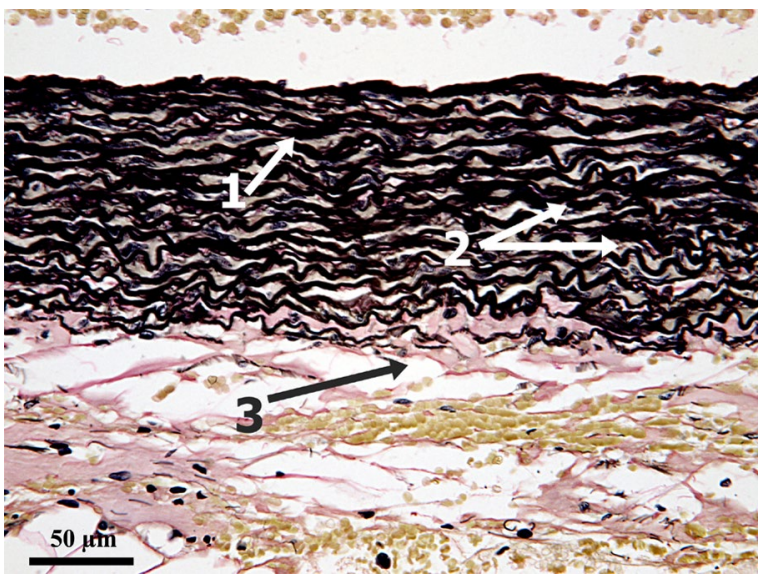

Figure 3. Aortic cross (Verhoeff); 1 - elastic laminae; 2 - smooth muscle cells; 3 - adventice.

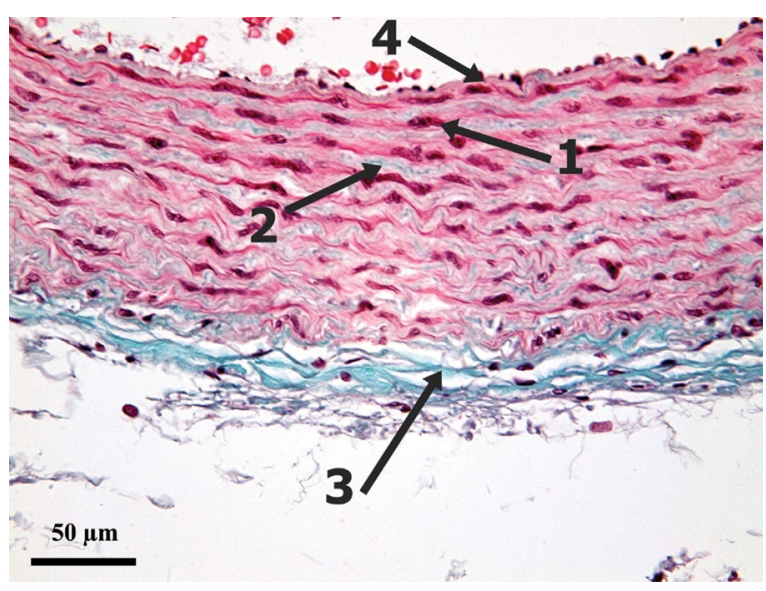

Figure 4. Aortic cross (Trichrome Goldner); 1 - muscle cells of the media; 2 - connective tissue of the media; 3 - adventice; 4 - intima.

muscular cells are ordered, showing a one single cell row arrangement intermingled in the medial layer of the studied samples (Fig. 4), the external limiting membrane not being evidenced.

Thoracic aorta. The thoracic aorta shows again similar aspects with the ones described previously, with elastic laminae disposed in a similar manner, with a slightly increased width when compared with the aortic cross segment (Fig. 5). In terms of number of laminae, there is a progressive decrease (14.43). The interlaminar spaces are visibly larger in the internal part of the artery, while the outermost medial part maintains a similar aspect with the previous aortic sectors. Although the interlaminar spaces are larger, the muscular component suffers no changes in terms of the described arrangement in the other aortic sec- 


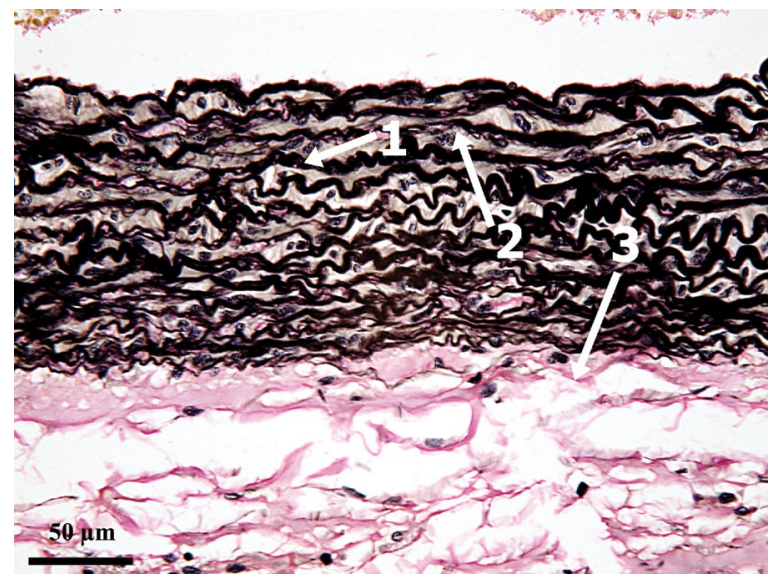

Figure 5. Thoracic aorta (Verhoeff); 1 - elastic laminae; 2 - smooth muscle cells of the media; 3 - adventice.

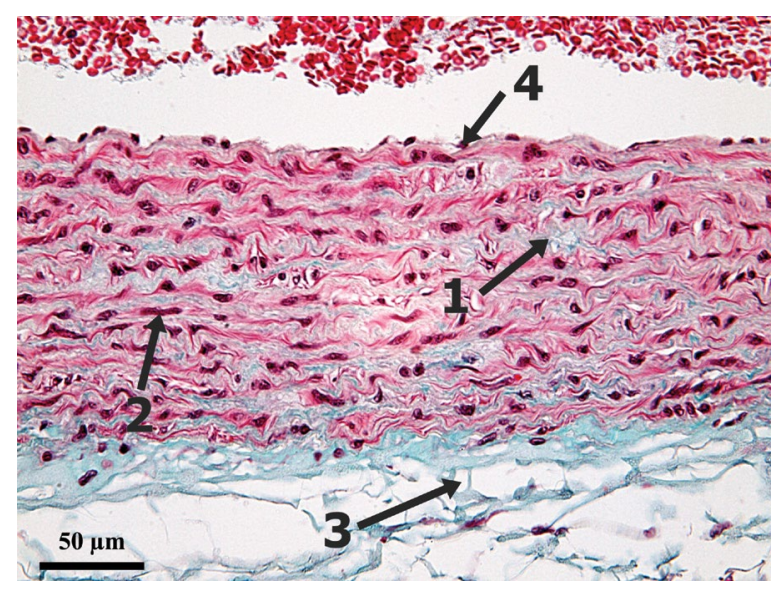

Figure 6. Thoracic aorta (Trichrome Goldner); 1 - connective tissue; 2 - smooth muscle cells; 3 - adventice; 4 - intima.

tors (Fig. 6). The internal limiting membrane cannot be differentiated from the other elastic laminae, the same standing for the external limiting membrane.

Abdominal aorta. In this sector, the width of the arterial wall is somehow reducing. The ratio between the three tunics is modified, with a slight decrease in the proportion of the media in favour of the adventice (Fig. 7).

The medial muscular cells are placed in rows between the elastic laminae in the scant interlaminar connective tissue (Fig. 8). The internal limiting membrane, still distinguishable, is not folded as in the previous aortic sectors, but seems a little thicker than the laminae deeply situated in the media. As in all sectors described so far, the external limiting membrane could not be identified.

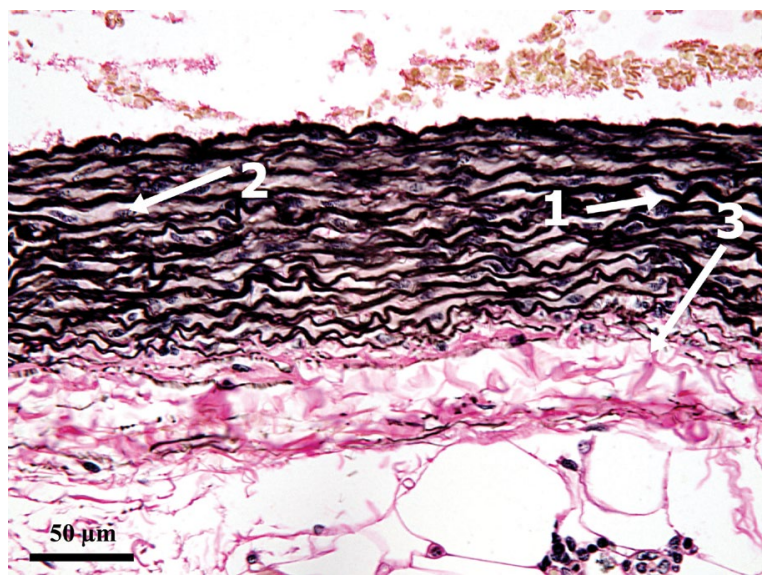

Figure 7. Abdominal aorta (Verhoeff); 1 - elastic laminae; 2 - smooth muscle cells; 3 - adventice.

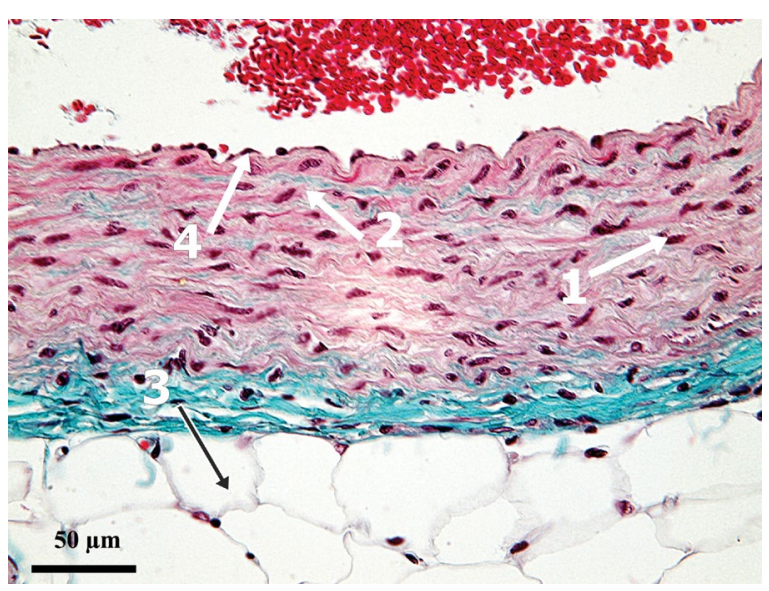

Figure 8. Abdominal aorta (Trichrome Goldner); 1 - smooth muscle cells of the media; 2 - connective tissue of the media; 3 - adventice; 4 - intima.

\section{Quantitative data}

In order to evaluate the specific values, a series of microscopic measurements were taken in respect of the thickness of intima, media and the number of the elastic laminae for each of the sectors studied. The results (shown as average values and standard deviations, minimal and maximal values) are shown in Table 1.

\section{Advanced statistics}

The results were comparatively analysed in conjunction with the observed morphological data. Data recorded from all studied segments were compared, in the attempt of finding differential elements from this metrical perspective.

Tunica interna (thickness). For the series of dimensions recorded in all studied sectors of the inti- 
Table 1. Quantitative data for the components of the aortic sectors (averages and standard deviation, $n=$ number of measurements)

\begin{tabular}{lcccc}
\hline & Intima & Media & Elastic laminae width & $\begin{array}{c}\text { Elastic laminae number } \\
\text { (average) }\end{array}$ \\
\hline Ascending aorta $[\mu \mathrm{m}]$ & $\begin{array}{c}3.77 \pm 0.8,(1.93-6.38), \\
\mathrm{n}=69\end{array}$ & $\begin{array}{c}179.93 \pm 22.8,(140.4-244.2), \\
\mathrm{n}=74\end{array}$ & $\begin{array}{c}2.60 \pm 0.7,(1.70-4.88), \\
\mathrm{n}=68\end{array}$ & $18.86, \mathrm{n}=61$ \\
Aortic cross $[\mu \mathrm{m}]$ & $3.82 \pm 0.51,(2.72-4.95)$, & $112.21 \pm 7.1,(96.18-125.05)$, & $2.76 \pm 0.5,(1.74-4.22)$, & $18.71, \mathrm{n}=49$ \\
& $\mathrm{n}=35$ & $\mathrm{n}=66$ & $\mathrm{n}=39$ & $14.43, \mathrm{n}=32$ \\
Thoracic aorta $[\mu \mathrm{m}]$ & $2.83 \pm 0.45,(1.62-3.98)$, & $\begin{array}{c}123.80 \pm 11.8,(91.97-142.09), \\
\mathrm{n}=41\end{array}$ & $\begin{array}{c}3.41 \pm 0.74,(1.97-6.64), \\
\mathrm{n}=55\end{array}$ & 129 \\
Abdominal aorta $[\mu \mathrm{m}]$ & $3.24 \pm 0.88,(1.7-5.67)$, & $115.73 \pm 11.8,(81.55-158.03)$, & $3.11 \pm 0.59,(1.95-5.73)$, & $19.71, \mathrm{n}=53$ \\
& $\mathrm{n}=61$ & $\mathrm{n}=47$ & $\mathrm{n}=81$ & \\
\hline
\end{tabular}

Table 2. Advanced statistics (post hoc) — intima measurements of different aortic sectors

\begin{tabular}{|c|c|c|c|c|c|c|}
\hline Segment & $\begin{array}{l}\text { Ascending aorta } \\
\text { vs. aortic cross }\end{array}$ & $\begin{array}{l}\text { Ascending aorta } \\
\text { vs. thoracic aorta }\end{array}$ & $\begin{array}{c}\text { Ascending aorta } \\
\text { vs. abdominal aorta }\end{array}$ & $\begin{array}{l}\text { Aortic cross vs. } \\
\text { thoracic aorta }\end{array}$ & $\begin{array}{l}\text { Aortic cross vs. } \\
\text { abdominal aorta }\end{array}$ & $\begin{array}{l}\text { Thoracic aorta vs. } \\
\text { abdominal aorta }\end{array}$ \\
\hline $\begin{array}{l}\text { Tukey } \\
\text { p-value }\end{array}$ & 0.8999947 & 0.0010053 & 0.0021494 & 0.0010053 & 0.0010053 & 0.0440389 \\
\hline $\begin{array}{l}\text { Tukey } \\
\text { inference }\end{array}$ & Insignificant & ${ }^{* *}, p<0.01$ & ${ }^{* *}, p<0.01$ & ${ }^{* *}, p<0.01$ & ${ }^{* *}, p<0.01$ & ${ }^{*}, p<0.05$ \\
\hline $\begin{array}{l}\text { Scheffe } \\
\text { p-value }\end{array}$ & 0.987155 & $1.63 \mathrm{e}-06$ & 0.053841 & $1.07 e-07$ & 0.001932 & 0.0762995 \\
\hline $\begin{array}{l}\text { Scheffe } \\
\text { inference }\end{array}$ & Insignificant & ${ }^{* *}, p<0.01$ & ${ }^{* *}, p<0.01$ & ${ }^{* *}, p<0.01$ & ${ }^{* *}, p<0.01$ & Insignificant \\
\hline $\begin{array}{l}\text { Bonferroni } \\
\text { p-value }\end{array}$ & 4.2738 & 3.32e-07 & 0.0022934 & $1.88 \mathrm{e}-08$ & 0.0007186 & 0.0537212 \\
\hline $\begin{array}{l}\text { Bonferroni } \\
\text { inference }\end{array}$ & Insignificant & ${ }^{* *}, p<0.01$ & ${ }^{* *}, p<0.01$ & ${ }^{* *}, p<0.01$ & ${ }^{* *}, p<0.01$ & Insignificant \\
\hline $\begin{array}{l}\text { Holm } \\
\text { p-value }\end{array}$ & 0.7123111 & $2.77 \mathrm{e}-07$ & 0.0011467 & $1.88 \mathrm{e}-08$ & 0.0004791 & 0.0179071 \\
\hline $\begin{array}{l}\text { Holm } \\
\text { inference }\end{array}$ & Insignificant & $*^{*}, p<0.01$ & $*^{*}, p<0.01$ & ${ }^{* *}, p<0.01$ & ${ }^{* *}, p<0.01$ & ${ }^{*}, p<0.05$ \\
\hline
\end{tabular}

ma, the applied post hoc test shows that the $p$-value corresponding to the F-statistic of one-way ANOVA is lower than 0.01 , which strongly suggests that one or more pairs of treatments are significantly different.

The Tukey test reveals (as shown in the Table 2 ) a significant difference $(* *, p<0.01)$ between the following pairs:

- ascending aorta vs. thoracic aorta and abdominal aorta, as well as in between the aortic cross vs. thoracic and abdominal aorta;

- and a small significance was shown in the case of abdominal aorta vs. thoracic aorta $\left({ }^{*}, \mathrm{p}<0.05\right)$;

- no significant differentiation in the case of values recorded for intima of ascending aorta vs. aortic cross.

In the case of Scheffe, Bonferroni and Holm tests, the results are similar, except for the thickness of the intima of thoracic and abdominal aorta, which seems to be statistically undifferentiated.

Tunica media (thickness). The p-value corresponding to the F-statistic of one-way ANOVA applied for the measurements of the media of studied sectors is lower than 0.05 , suggests that the one or more groups are significantly different (Table 3).

The Tukey HSD test, Scheffé, Bonferroni and Holm multiple comparison tests follow. Based on the comparison of the series, results were computed:

Tables 1 and 2 shows degree of differentiation $\left({ }^{* *}\right)$ in respect of the values of the media in the case of:

- ascending aorta vs. aortic cross (all tests), ascending aorta vs. thoracic aorta;

- aortic cross vs. thoracic and abdominal aorta (all tests). 
Table 3. Advanced statistics (post hoc) — media measurements of different aortic sectors

\begin{tabular}{|c|c|c|c|c|c|c|}
\hline Segment & $\begin{array}{l}\text { Ascending aorta } \\
\text { vs. aortic cross }\end{array}$ & $\begin{array}{l}\text { Ascending aorta } \\
\text { vs. thoracic aorta }\end{array}$ & $\begin{array}{c}\text { Ascending aorta } \\
\text { vs. abdominal aorta }\end{array}$ & $\begin{array}{l}\text { Aortic cross vs. } \\
\text { thoracic aorta }\end{array}$ & $\begin{array}{l}\text { Aortic cross vs. } \\
\text { abdominal aorta }\end{array}$ & $\begin{array}{l}\text { Thoracic aorta vs. } \\
\text { abdominal aorta }\end{array}$ \\
\hline $\begin{array}{l}\text { Tukey } \\
\text { p-value }\end{array}$ & 0.0010053 & 0.0010053 & 0.60170 & 0.0010053 & 0.0010053 & 0.0461158 \\
\hline $\begin{array}{l}\text { Tukey } \\
\text { inference }\end{array}$ & ${ }^{* *} p<0.01$ & ${ }^{* *} p<0.01$ & Insignificant & ${ }^{* *} p<0.01$ & ${ }^{* *} p<0.01$ & ${ }^{*} p<0.05$ \\
\hline $\begin{array}{l}\text { Scheffe } \\
\text { p-value }\end{array}$ & $1.1102 \mathrm{e}-16$ & 0.0006922 & 0.6857347 & $1.1102 \mathrm{e}-16$ & $1.1102 \mathrm{e}-16$ & 0.0794786 \\
\hline $\begin{array}{l}\text { Scheffe } \\
\text { inference }\end{array}$ & ${ }^{* *} p<0.01$ & ${ }^{* *} p<0.01$ & Insignificant & ${ }^{* *} p<0.01$ & ${ }^{* *} p<0.01$ & Insignificant \\
\hline $\begin{array}{l}\text { Bonferroni } \\
\text { p-value }\end{array}$ & $0.0000 \mathrm{e}-00$ & 0.0002275 & 1.3437801 & $0.0000 \mathrm{e}-00$ & $0.0000 \mathrm{e}-00$ & 0.0564001 \\
\hline $\begin{array}{l}\text { Bonferroni } \\
\text { inference }\end{array}$ & ${ }^{* *} p<0.01$ & ${ }^{* *} p<0.01$ & Insignificant & ${ }^{* *} p<0.01$ & ${ }^{* *} p<0.01$ & Insignificant \\
\hline $\begin{array}{l}\text { Holm } \\
\text { p-value }\end{array}$ & $0.0000 \mathrm{e}-00$ & 0.0001137 & 0.2239633 & $0.0000 \mathrm{e}-00$ & $0.0000 \mathrm{e}-00$ & 0.018800 \\
\hline $\begin{array}{l}\text { Holm } \\
\text { inference }\end{array}$ & ${ }^{* *} p<0.01$ & ${ }^{* *} p<0.01$ & Insignificant & ${ }^{* *} p<0.01$ & ${ }^{* *} p<0.01$ & \\
\hline
\end{tabular}

In the case of the values of media of thoracic and abdominal aorta, no or very little differentiation (Holm test) is shown. Similarly, an insignificant difference is shown in the case of values of ascending aorta versus abdominal aorta.

Elastic laminae (thickness). The p-value corresponding to the F-statistic of one-way ANOVA is lower than 0.05 , suggesting that the one or more treatments are significantly different.

\section{The Tukey HSD test, Scheffé, Bonferroni} and Holm multiple comparison tests

All three applied tests show the fact that statistically there seems no differentiation between the number of elastic laminae recorded at the level of the ascending aorta and the aortic cross, while on the other hand, slight differences between the segments are noticeable as we advance further from the initial aortic part (aortic cross vs. thoracic or abdominal aorta, ascending aorta vs. thoracic and abdominal aorta) (Table 4).

\section{Regional variations of the tunics}

Regional variations in tunica intima. The intima consists of the endothelial layer placed on the basal membrane, a subendothelial layer and the internal elastic lamina. The average values recorded for the thickness of the intima show a mentionable decrease in the case of the thoracic segment of the aorta $(2.83 \mu \mathrm{m})$, with close values for the ascending aorta
(3.77 $\mu \mathrm{m})$, aortic cross $(3.82 \mu \mathrm{m})$, while the intima of abdominal aorta shows a small decrease only $(3.24 \mu \mathrm{m})$.

The internal limiting membrane is thin, visible in the ascending aorta, but as we progress towards the abdominal aorta, the structure becomes less and less distinguishable, not being differentiated from other elastic laminae (thoracic and abdominal aorta).

The appearance of the layer seems relatively uniform in all segments, with another worth-mentioning feature that refers to the folding degree of the intima, in the abdominal sector a limited amount of folding being recorded when compared to the other segments.

The complex statistical analysis of the thickness figures shows an interesting feature of the data rows. The post hoc tests indicate a certain degree of differentiation for all compared sets, with significant differences among sectors. Although the values seem very similar in terms of averages, there is a significant statistical difference between ascending aorta, thoracic and abdominal computed aorta values.

Regional variations in tunica media. The medial layer the thickest coat of the three portions analysedconsists of elastic laminae, collagen fibres and smooth muscle cells in an interrelated arrangement.

The overall thickness (as average value) of the medial layer shows a decrease in dimensions from the ascending aorta towards the abdominal aorta.

The orientation of the elastic laminae maintains a predominantly circular arrangement in all studied. 
Table 4. Advanced statistics (post hoc) — number of elastic laminae of different aortic sectors

\begin{tabular}{|c|c|c|c|c|c|c|}
\hline Segment & $\begin{array}{l}\text { Ascending aorta } \\
\text { vs. aortic cross }\end{array}$ & $\begin{array}{c}\text { Ascending aorta } \\
\text { vs. thoracic aorta }\end{array}$ & $\begin{array}{c}\text { Ascending aorta } \\
\text { vs. abdominal aorta }\end{array}$ & $\begin{array}{l}\text { Aortic cross vs. } \\
\text { thoracic aorta }\end{array}$ & $\begin{array}{l}\text { Aortic cross vs. } \\
\text { abdominal aorta }\end{array}$ & $\begin{array}{l}\text { Thoracic aorta vs. } \\
\text { abdominal aorta }\end{array}$ \\
\hline $\begin{array}{l}\text { Tukey } \\
\text { p-value }\end{array}$ & 0.6018440 & 0.0010053 & 0.0093116 & 0.0010053 & 0.010053 & 0.0094489 \\
\hline $\begin{array}{l}\text { Tukey } \\
\text { inference }\end{array}$ & Insignificant & ${ }^{* *} p<0.01$ & ${ }^{* *} p<0.01$ & ${ }^{* *} p<0.01$ & ${ }^{* *} p<0.01$ & ${ }^{* *} p<0.01$ \\
\hline $\begin{array}{l}\text { Scheffe } \\
\text { p-value }\end{array}$ & 0.6860750 & $1.5891 \mathrm{e}-08$ & 0.0198735 & $5.8366 \mathrm{e}-09$ & 0.0017750 & 0.0201326 \\
\hline $\begin{array}{l}\text { Scheffe } \\
\text { inference }\end{array}$ & Insignificant & ${ }^{* *} p<0.01$ & ${ }^{*} p<0.05$ & ${ }^{* *} p<0.01$ & ${ }^{* *} p<0.01$ & ${ }^{*} p<0.05$ \\
\hline $\begin{array}{l}\text { Bonferroni } \\
\text { p-value }\end{array}$ & 1.3437624 & $2.4692 \mathrm{e}-09$ & 0.0103576 & $8.6658 \mathrm{e}-10$ & 0.0006446 & 0.0105179 \\
\hline $\begin{array}{l}\text { Bonferroni } \\
\text { inference }\end{array}$ & Insignificant & ${ }^{* *} p<0.01$ & ${ }^{*} p<0.05$ & ${ }^{* *} p<0.01$ & ${ }^{* *} p<0.01$ & ${ }^{*} \mathrm{p}<0.05$ \\
\hline $\begin{array}{l}\text { Holm } \\
\text { p-value }\end{array}$ & 0.2239604 & $2.0577 \mathrm{e}-09$ & 0.0051788 & $8.6658 \mathrm{e}-10$ & 0.0004297 & 0.0035060 \\
\hline $\begin{array}{l}\text { Holm } \\
\text { inference }\end{array}$ & Insignificant & ${ }^{* *} p<0.01$ & ${ }^{* *} p<0.01$ & ${ }^{* *} p<0.01$ & ${ }^{* *} p<0.01$ & \\
\hline
\end{tabular}

The number of laminae does not vary significantly in different aortic regions, the average number of fibres being 18-19 in ascending aorta, aortic cross and abdominal aorta, with a worth-mentioning exception in the case of thoracic aorta (14 lamellae).

In terms of the diameter of the elastic laminae, one must notice the significant increase in the width of abdominal aorta $(3.11 \mu \mathrm{m})$ and thoracic aorta $(3.40 \mu \mathrm{m})$ in opposition to slightly increasing values recorded in ascending aorta $(2.6 \mu \mathrm{m})$ and aortic cross $(2.7 \mu \mathrm{m})$.

The muscle cells have a constant pattern of arrangement (row arrangement), with no significant changes from one sector to another, being slightly denser in the inner half of the arterial wall in all segments. The interlaminar spaces follow a similar pattern, with larger spaces in the inner half, while in the outermost half these spaces are narrower. This aspect is correlated with the slight increase on the prominence and folding of the elastic laminae within the media layer.

\section{DISCUSSION}

Based on the constituents, all investigated sectors of the aorta in chinchilla can be included in the elastic type, as described by a series of other authors $[2,4$, 8, 28, 32].

The intimal layer's structure depends on the level of the hemodynamic stimulation $[7,11,12,25]$. The folding degree of the intima and the underlying limit- ing membrane, explained dynamically as a resistance mechanism to the dilatation during systolic activity and as a reserve of intima stretched by systole [25], seems to decrease in the abdominal sector of the aorta, maintaining a relatively uniform folding in the other sectors. This suggests a different pattern in forces distribution within this sector, but things should be regarded in conjunction to the fact that the internal limiting membrane is not distinguishable microscopically in the last part of the aorta. Another interesting fact is represented by the change in thickness of the intima in the thoracic sector. The values for this sector are reported as being somehow similar to the case of Guinea pig and rat, where a difference of more than $10 \%$ can be noticed [22], similarly with our data sets. The advanced statistical investigation shows a low differentiation for the first two initial sectors (ascending aorta and aortic cross), but clear differentiation between values of the next sectors (mainly thoracic and abdominal aorta).

The media plays the most important haemodynamic role (windkessel function) [35], related to the influence of the systolic pressure and turbulent blood flow during ventricular systole $[11,25]$.

The overall width of the media shows a decrease in width from the ascending aorta $(170 \mu \mathrm{m})$ to a relatively constant dimension of 110-120 $\mu \mathrm{m}$ in the rest of the sectors, despite the fact that the advanced statistics indicates some kind of differentiation among sectors, with the exception of the thoracic aorta data. 
The quantity of elastic laminae in different sectors of the aorta shows a significant decrease in number only in the area of the thoracic aorta (from 18-19 to 14). The data is partially confirmed by the advanced statistics in respect of the dimensions of elastic laminae, mainly in the case of differentiation of ascending aorta and descending aortic sectors; a situation that does not resemble the comparative data that was earlier published. As an example, in Guinea pig the number of laminae decreases from 29 in ascending sector to 15 in thoracic and 8 in abdominal sector, with a somehow similar decrease in rat (12 in ascending aorta, 9 thoracic aorta and 7 in abdominal aorta) $[2,22]$. Opposed to this situation, in dog the number of elastic laminae in aortic segments is much higher (30-40 in ascending and thoracic descending aorta decreasing to 15 in the abdominal part) [21]. On the other hand, the number of elastic fibres in chinchilla's medial layer seems to be correlated with a change in width of the laminae in the case of the thoracic aorta. Here a reduction in the average number must be noticed, as a possible explanation for the slight physiological decrease in the aortic pressure in this sector and reduction in the mural resistance (as implied by Mello et al. [22]), possibly due to a limited number of collaterals emitted in the thoracic sector. Another explanation arises from the morphological observation on the interlaminar spaces [6] that are much larger than in the other sectors, filled with stronger bundles of muscular cells.

\section{CONCLUSIONS}

The observations of the present study show that the coats of the different sectors of the aorta in chinchilla display a series of interesting qualitative and quantitative regional variations, some perceivable by means of simple statistical parameters, some others by means of advanced statistical methods.

A series of functional correlations can be made on this basis, mainly related to haemodynamic factors. These observations may also serve as a starting point for understanding the differences in functional mechanics and physiology in different sectors and maybe some pathological phenomena that can be associated with these arterial segments.

\section{REFERENCES}

1. Al-Jarallah A, Akinpelu OV, Citra D, et al. Ototoxicity of baby oil in a chinchilla animal model. Int J Pediatr Otorhinolaryngol. 2012; 76(4): 564-568, doi: 10.1016/j. ijporl.2012.01.018, indexed in Pubmed: 22348846.
2. Awal MA, Matsumoto M, Nishinakagawa H. Morphometrical changes of the arterial walls of main arteries from heart to the abdomino-inguinal mammary glands of rat from virgin through pregnancy, lactation and post-weaning. J Vet Med Sci. 1995; 57(2): 251-256, doi: 10.1292/ jvms.57.251, indexed in Pubmed: 7492641.

3. Barone R. Anatomie comparee des mammiferes domesticques. Tome cinquieme. Angiologie. Editions Vigot, Paris 1996.

4. Clark JM, Glagov S. Transmural organization of the arterial media. The lamellar unit revisited. Arteriosclerosis. 1985; 5(1): 19-34, indexed in Pubmed: 3966906.

5. Cooper G, Schiller A. Anatomy of the Guinea pig. Nature. 1976; 260(5548): 204-204, doi: 10.1038/260204d0.

6. Csibi D, Miclaus V, Martonos C, et al. Proportional representation and structure of tunicae in large arteries in rabbit. Bull Univ Agric Sci Vet Med Cluj-Napoca Vet Med. 2014; 71(2): 395-401, doi: 10.15835/buasvmcn-vm:10548.

7. Davies PF, Zilberberg J, Helmke BP. Spatial microstimuli in endothelial mechanosignaling. Circ Res. 2003; 92(4): 359-370, doi: 10.1161/01.RES.0000060201.41923.88, indexed in Pubmed: 12623874.

8. Dingemans $\mathrm{KP}$, Jansen $\mathrm{N}$, Becker AE. Ultrastructure of the normal human aortic media. Virchows Arch A Pathol Anat Histol. 1981; 392(2): 199-216, doi: 10.1007/BF00430821, indexed in Pubmed: 7281508.

9. Eurell JA, Brian L. Frappier Dellmann's Textbook of Veterinary Histology, 6th ed. Wiley-Blackwell, Blackwell Publishing, Ames, lowa, USA 2007.

10. Filho SPG, Martins LL, Reis A, et al. Estrutura, ultraestrutura e morfometria da aorta de paca (Cuniculus paca, Linnaeus, 1766) criada em cativeiro. Arq Bras Med Vet Zootec. 2012; 64(3): 599-605, doi: 10.1590/s010209352012000300011.

11. Gibbons CA, Shadwick RE. Functional similarities in the mechanical design of the aorta in lower vertebrates and mammals. Experientia. 1989; 45(11-12): 1083-1088, doi: 10.1007/bf01950164, indexed in Pubmed: 2513219.

12. Gibbons CA, Shadwick RE. Circulatory Mechanics in the Toad Bufo Marinus: I. Structure and Mechanical Design of the Aorta. J Exp Biol 158. 1991; 275: LP-289.

13. Giebink GS. Otitis media: the chinchilla model. Microb Drug Resist. 1999; 5(1): 57-72, doi: 10.1089/ mdr.1999.5.57, indexed in Pubmed: 10332723.

14. Hitt BM, Wang X, Gan RZ. Dynamic property changes in stapedial annular ligament associated with acute otitis media in the chinchilla. Med Eng Phys. 2017; 40: 65-74, doi: 10.1016/j.medengphy.2016.12.003, indexed in Pubmed: 27989383.

15. Kerschner JE, Khampang $P$, Samuels T. Extending the chinchilla middle ear epithelial model for mucin gene investigation. Int J Pediatr Otorhinolaryngol. 2010; 74(9): 980-985, doi: 10.1016/j.ijporl.2010.05.009, indexed in Pubmed: 20591507.

16. Komolafe OA, Adeyemi DO, Adewole OS, et al. Morphological and morphometric studies of the aorta, pulmonary trunk, and heart of streptozotocin-induced diabetic Wistar rats. Folia Morphol. 2009; 68(4): 207-214, indexed in Pubmed: 19950068.

17. Locquin MV, Langeron M, Hillman H. Handbook of microscopy. Butterworth, Heinemann 2013. 
18. Maravilla P, Garza-Rodriguez A, Gomez-Diaz B, et al. Chinchilla laniger can be used as an experimental model for Taenia solium taeniasis. Parasitol Int. 2011; 60(4): 364-370, doi: 10.1016/j.parint.2011.06.002, indexed in Pubmed: 21723412.

19. Martins M, Silva JP, Martins B. Contribution to the Study of Aortic Mural Structure of Opossum (Didelphis albiventris). Int J Morphol. 2010; 28(1): 277-282, doi: 10.4067/ s0717-95022010000100041.

20. Martonos C, Dezdrobitu C, Rus V, et al. Distributon of the Terminals of the Descending Abdominal Aorta in Chinchillas. Bull Univ Agric Sci Vet Med Cluj-Napoca Vet Med. 2014; 71(2), doi: 10.15835/buasvmcn-vm:10498.

21. Mello J, Orsi A, Domingues R, et al. Arquitetura da parede vascular de segmentos torácico e abdominais da aorta de macaco prego (Cebus apella). Brazilian J Vet Res Anim Sci. 2009; 46(1): 40, doi: 10.11606/issn.1678-4456. bjvras.2009.26748.

22. Mello JM, Orsi AM, Padovani CR. Structure of the aortic wall in the guinea pig and rat. Braz J Morphol. 2004; 21: 35-38.

23. Mello J, Orsi A, Padovani C, et al. Some segmental structural features of the aortic wall of domestic chicken (Gallus domesticus). Brazilian J Vet Res Anim Sci. 2003; 40: 163-169, doi: 10.1590/s1413-95962003000900001.

24. Ogeng'o JA, Malek AA, Kiama SG. Structural organisation of tunica intima in the aorta of the goat. Folia Morphol. 2010; 69(3): 164-169, indexed in Pubmed: 21154287.

25. Ogeng'o JA, Malek AKA, Kiama SG. Regional differences in aorta of goat (capra hircus). Folia Morphol. 2010; 69(4): 253-257, indexed in Pubmed: 21120813.

26. Oliveira REM. de, Júnior HN de A, Costa H da S, Oliveira GB de, Moura CEB de, Menezes DJA de, Oliveira MF de Artérias colaterais do arco aórtico do gerbil (Meriones unguiculatus ). Acta Sci Vet. 2018; 55: 1-8, doi: 10.22456/16799216.79176.85987.

27. Orsi AM, Stefanini MA, Crocci AJ, et al. Some segmental features on the structure of the aortic wall of the dog. Anat Histol Embryol. 2004; 33(3): 131-134, doi: 10.1111/j.1439-0264.2004.00410.x, indexed in Pubmed: 15144278.

28. Osborne-Pellegrin MJ. Some ultrastructural characteristics of the renal artery and abdominal aorta in the rat. J Anat. 1978; 125(Pt 3): 641-652, indexed in Pubmed: 640965.

29. Ozdemir V, Cevik-Demirkan A, Türkmenoğlu I. Subgross and macroscopic investigation of blood vessels originating from aortic arch in the chinchilla (Chinchilla lanigera). Anat Histol Embryol. 2008; 37(2): 131-133, doi: 10.1111/j.1439-0264.2007.00808.x, indexed in Pubmed: 18005370.

30. Ozdemir V, Cevik Demirkan A, Akosman MS. Subgross and macroscopic investigation of the coeliac artery in the chinchilla (chinchilla lanigera). Folia Morphol. 2013; 72(3): 258-262, indexed in Pubmed: 24068688.

31. Ozdemir V, Cevik-Demirkan A, Turkmenoglu I. The right coronary artery is absent in the chinchilla (Chinchilla lanigera). Anat Histol Embryol. 2008; 37(2): 114-117, doi: 10.1111/j.14390264.2007.00803.x, indexed in Pubmed: 18005371.

32. Prodan M. Histological Studies on the Arterial Walls of Main Arteries Supplying the Mammary Glands of Dogs (Canis familiaris) in Bangladesh. Pakistan J Biol Sci. 2001; 4(12): 1568-1571, doi: 10.3923/pjbs.2001.1568.1571.

33. Qi M, Luo N, Wang H, et al. Zoonotic Cryptosporidium spp. and Enterocytozoon bieneusi in pet chinchillas (Chinchilla lanigera) in China. Parasitol Int. 2015; 64(5): 339-341, doi: 10.1016/j.parint.2015.05.007, indexed in Pubmed: 25988830.

34. Suckow M, Stevens K, Wilson R. The Laboratory Rabbit, Guinea Pig, Hamster, and Other Rodents. Academic Press, ELservier Inc. 2012, p. 1280.

35. Westerhof N, Lankhaar JW, Westerhof BE. The arterial Windkessel. Med Biol Eng Comput. 2009; 47(2): 131-141, doi: 10.1007/s11517-008-0359-2, indexed in Pubmed: 18543011.

36. Zaki SM, Youssef MF. Thyroid hormone dysfunctions affect the structure of rat thoracic aorta: a histological and morphometric study. Folia Morphol. 2013; 72(4): 333-339, indexed in Pubmed: 24402756. 